\title{
The global distribution of Plasmodium vivax and G6PD deficiency prevalence
}

\author{
Simon I Hay \\ From Challenges in malaria research \\ Basel, Switzerland. 10-12 October 2012
}

Existing understanding of the spatial epidemiology and geographical distribution of Plasmodium vivax is poor. Here we present the first systematic effort to map its endemicity globally. Routine case reporting data were assembled from 17,893 administrative units across the 95 $P$. vivax endemic countries and combined with biological risk exclusion layers and other medical intelligence data to update the estimated global limits of $P$. vivax transmission for 2010. Within areas of stable transmission, a second assembly of 9,970 quality-checked and geopositioned $P$. vivax parasite rate surveys were used with a spatiotemporal Bayesian model-based geostatistical approach to estimate endemicity age-standardised to the 1-99 year age range within every $5 \times 5 \mathrm{~km}$ resolution grid square. The model incorporated prevalence data on the refractory Duffy negativity phenotype to appropriately suppress risk predictions, particularly in Africa. Endemicity was predicted within a relatively narrow range of prevalence throughout the endemic world with the point estimate rarely exceeding $7 \%$. These patterns are described. Radical cure of $P$. vivax requires treatment of the parasite's dormant relapsing life stages, for which primaquine is the only drug licenced. This drug may, however, trigger mild to severe haemolysis in patients with a genetically determined deficiency in glucose-6-phosphate dehydrogenase production (G6PDd). We therefore also present the first evidence-based continuous prevalence map of G6PDd globally. Representative community surveys of phenotypic G6PDd prevalence were identified for 1,734 spatiallyunique sites globally. These formed the evidence-base for a Bayesian geostatistical model adapted to the G6PD gene's X-linked inheritance mechanism, which generated a G6PDd allele frequency map across malaria endemic

University of Oxford, UK

(c) 2012 Hay; licensee BioMed Central Ltd. This is an Open Access article distributed under the terms of the Creative Commons Attribution License (http://creativecommons.org/licenses/by/2.0), which permits unrestricted use, distribution, and reproduction in any medium, provided the original work is properly cited. countries. The resulting maps and population estimates reflect potential risk of primaquine-associated harm.

Published: 15 October 2012

doi:10.1186/1475-2875-11-S1-02

Cite this article as: Hay: The global distribution of Plasmodium vivax and G6PD deficiency prevalence. Malaria Journal 2012 11(Suppl 1):O2.

Submit your next manuscript to BioMed Central and take full advantage of:

- Convenient online submission

- Thorough peer review

- No space constraints or color figure charges

- Immediate publication on acceptance

- Inclusion in PubMed, CAS, Scopus and Google Scholar

- Research which is freely available for redistribution

Submit your manuscript at www.biomedcentral.com/submit \\ () Biomed Central}

